\title{
INTRODUCING \\ Psychological Research
}


Also by Philip Banyard

Psychology: Theory AND APPLication (with Nicky Hayes)

Applying Psychology to Health 


\section{INTRODUCING}

PSYCHOLOGICAL RESEARCH

Sixty Studies that Shape Psychology

Philip Banyard and Andrew Grayson

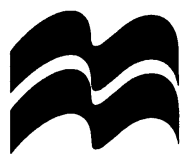


(C) Philip Banyard and Andrew Grayson 1996

All rights reserved. No reproduction, copy or transmission of this publication may be made without written permission.

No paragraph of this publication may be reproduced, copied or transmitted save with written permission or in accordance with the provisions of the Copyright, Designs and Patents Act 1988, or under the terms of any licence permitting limited copying issued by the Copyright Licensing Agency, 90 Tottenham Court Road, London W1P 9HE.

Any person who does any unauthorised act in relation to this publication may be liable to criminal prosecution and civil claims for damages.

First published 1996 by

MACMILLAN PRESS LTD

Houndmills, Basingstoke, Hampshire RG21 6XS

and London

Companies and representatives

throughout the world

ISBN 978-0-333-62005-2

ISBN 978-1-349-24483-6 (eBook)

DOI 10.1007/978-1-349-24483-6

A catalogue record for this book is available from the British Library

$\begin{array}{cccccccccc}10 & 9 & 8 & 7 & 6 & 5 & 4 & 3 & 2 & 1 \\ 05 & 04 & 03 & 02 & 01 & 00 & 99 & 98 & 97 & 96\end{array}$

Typeset in Great Britain by Aarontype Limited

Easton, Bristol 


\section{Contents}

List of Figures xiv

List of Tables xvii

Preface $\quad \mathrm{xx}$

Acknowledgements xxii

Part I: Social Psychology

1 Social Pressure 3

Eight Out of Ten OWners Said Their Cats Preferred It 5

- AsCH, S.E. (1955). Opinions and social pressure. Scientific American, 193, 31-35.

HeLPING BeHAVIOUR

口 Piliavin, I.M., Rodin, J.A. \& Piliavin, J. (1969). Good samaritanism: An underground phenomenon? Journal of Personality and Social Psychology, 13, 289-99.

Be A Good Boy and Do As You Are Told

- Milgram, S. (1963). Behavioral study of obedience. Journal of Abnormal and Social Psychology, 67, 371-78.

\section{Social Cognition}

Is She ReAlly Going Out With Him?

- Nisbett, R.E., Caputo, C., Legant, P. \& MareceK, J. (1973). Behaviour as seen by the actor and as seen by the observer. Journal of Personality and Social Psychology, 27, 154-64.

I'm Not Prejudiced, But ...

LAPiere, R.T. (1934). Attitudes vs. actions. Social Forces, 13, 230-37. 
vi CONTENTS

Changing our Minds

- Festinger, L. \& CARlsmith, J. M.(1959).

Cognitive consequences of forced compliance.

Journal of Abnormal and Social Psychology, 58, 203-10.

3 Social Roles

The Prison Simulation

- Haney, C., Banks, W.C. \& Zimbardo, P.G. (1973).

A study of prisoners and guards in a simulated prison. Naval Research Review, 30,4-17.

BEHAVIOUR IN GROUPS

- BALES, R.F. (1955). How people interact in conferences. Scientific American, 192, 31-35.

4 Prejudice

The Robber's CAVE

- SHERIF, M. (1956). Experiments in group conflict. Scientific American, 195, 54-58.

The Jigsaw Technigue

aronson, E. \& Bridgeman, D. (1979). Jigsaw groups and the desegregated classroom: In pursuit of common goals. In E.Aronson (ed.), Readings about the Social Animal, 6th edn, pp. 329-40; originally in Personality and Social Psychology Bulletin, 5, 438-66.

The Minimal Group Studies

- TAJFEL, H. (1970).

Experiments in intergroup discrimination.

Scientific American, 223, 96-102.

\section{Part II: Comparative and Physiological Psychology}

The Flight of the Killer Pigeons

- Skinner, B.F. (1960). Pigeons in a pelican. American Psychologist 15, 28-37.

LeAR Ning to be Helpless

- Seligman, M.E.P. \& Maier, S.F. (1967).

Failure to escape traumatic shock Journal of Experimental Psychology, 74, 1-9. 
TAlking to the ANimals

- GARDNER, R.A. \& GARDNER, B.T. (1969). Teaching sign language to a chimpanzee. Science, 165, 664-72.

6 Bio-psychology

A Brain of Two Halves

- SPERRY, R.W. (1968). Hemisphere deconnection and unity in conscious awareness. American Psychologist, 23, 723-33.

HOW DO YOU FEEL?

103

- SChachter, S. \& Singer, J.E. (1962). Cognitive, social and physiological determinants of emotional state. Psychological Review, 69, 379-99.

To Sleep, Perchance to Dream

- Dement, W. And Kleitman, N. (1957). The relation of eye movements during sleep to dream activity: An objective method for the study of dreaming. Journal of Experimental Psychology, 53, 339-46.

7 Ethology

The Colony of Monkeys

- Rawlins, R. (1979). Forty years of rhesus research. New Scientist, (12 April 1979), 108-10.

A Fishy TALE

- Tinbergen, N. (1952). The curious behaviour of the stickleback. Scientific American, 187, 22-26.

Rat City: The Behavioural Sink

- Calmoun, J.B. (1962). Population density and social pathology.

Scientific American, 206, 139-48.

\section{PART III: Human Diversity}

- Kitтo, J. (1989). Gender reference terms: Separating the women from the girls. British Journal of Social Psychology, 28, 185-87. 
LEARNING TO FAIL

DWeck, C.S., Davidson, W., Nelson, S. \& EnNa, B. (1978). Sex differences in learned helplessness:

II. The contingencies of evaluative feedback in the classroom and III. An experimental analysis.

Developmental Psychology, 14, 268-76.

Rites of Passage

- Koff, E. (1983). Through the looking glass of menarche: What the adolescent girl sees.

In S. Golub (ed.), Menarche, pp.77-86. Lexington, Mass: D.C. Heath.

\section{Measuring Personality}

Measuring Masculinity and Femininity

- BEM, S. (1974). The measurement of psychological androgyny. Journal of Consulting and Clinical Psychology, 42, 155-62.

How Gullible Are You?

- ForER, B.R. (1949). The fallacy of personal validation: A classroom demonstration of gullibility. Journal of Abnormal and Social Psychology, 44, 118-21.

10 Cultural Diversity

MIS-MEASURING INTELLIGENCE

- Gould, S.J. (1982). A nation of morons. New Scientist (6 May 1982), 349-52.

Black Dolls and White Dolls

- HrabA, J. \& Grant, G. (1970). Black is beautiful: A re-examination of racial preference and identification. Journal of Personality and Social Psychology, 16, 398-402.

BLACK IDENTITY

- Nobles, W. W. (1976). Extended self: Rethinking the so-called Negro self-concept. Journal of Black Psychology, 2.

\section{Abnormality}

You Don't Have to be Mad to Work Here. You Don't Even HaVe to Be Mad to Be In Here...

Rosenhan, D.L. (1973). On being sane in insane places. Science, 179, 250-58. 
Shrink Wrapped: The ChOICE OF Therapist

- SMITH, M.L. \& GLASs, G.V. (1977). Meta-analysis of psychotherapy outcome studies. American Psychologist, 32, 752-60.

The Three Faces of Eve 202

- Thigpen, C.H. \& Cleckley, H. (1954). A case of multiple personality. Journal of Abnormal and Social Psychology, 49, 135-51.

FeAr TODAy, Gone TOMORRow

208

- LANG, P.J. \& LAZOviK, A.D. (1963). Experimental desensitization of a phobia. Journal of Abnormal and Social Psychology, 66, 519-25.

Part IV: Developmental Psychology

12 Attachment

Can You Hear Me Mother?

- HaRlow, H.F. (1959). Love in infant monkeys. Scientific American, 200, 68-74.

FAMILY LifE

- Hodges, J. \& Tizard, B. (1989b). Social and family relationships of ex-institutional adolescents. Journal of Child Psychology and Psychiatry, 30, 77-97.

EMOTIONAL DEPRIVATION

- Koluchová, J. (1972). Severe deprivation in twins: A case study. Journal of Child Psychology and Psychiatry, 13, 107-14.

13 Moral Development

- KoHLBerg, L. (1968). The child as a moral philosopher. PsychologyToday, 2, 25-30.

The Moral Principle of Care

- Gilligan, C. \& Attanucci, J. (1988). Two moral orientations: Gender differences and similarities. Merrill-Palmer Quarterly, 34, 223-37. 
- Bandura, A., Ross, D. \& Ross, S.A. (1961).

Transmission of aggression through imitation of aggressive models.

Journal of Abnormal and Social Psychology, 63, 575-82.

14 The Classic Approaches

I Want a Girl, Just Like the Girl, That Married Dear OLD DAD

- Freud, S. (1909). Analysis of a phobia of a five-year-old boy. In The Pelican Freud Library (1977), Vol 8, Case Histories 1, pp. 169-306.

Piaget's Cognitive Approach

口 SAmuel, J. \& BRyant, P. (1984). Asking only one question in the conservation experiment. Journal of Child Psychology and Psychiatry, 25, 315-18.

The Tale of Little Albert

- Watson, J.B. \& RAYNER, R. (1920). Conditioned emotional reactions. Journal of Experimental Psychology, 3, 1-14.

15 Communication

The Dance of the Neonates

- Condon, W.S. \& SANDER, L.W. (1974). Neonate movement is synchronized with adult speech: Interactional participation and language acquisition. Science, 183, 99-101.

LISTEN WITH MOTHER

- Fernald, A. (1985). Four-month-old infants prefer to listen to motherese. Infant Behavior and Development, 8, 181-95.

- LABOV, W. (1969). The logic of nonstandard English. In P.P. Giglioli (ed.), Languages and Social Context, pp. 179-215. Harmondsworth, England: Penguin; originally in Georgetown Monographs on Language and Linguistics, 22, 1-31. 
Part V: Cognitive Psychology 295

16 Memory 297

Remembering Pictures 299

- Bartlett, F.C. (1932). Remembering: A Study in Experimental and Social Psychology, pp. 177-85.

EXEWITNESS TESTIMONY

305

- Loftus, E.F. \& Palmer, J.C. (1974). Reconstruction of automobile destruction: An example of the interaction between language and memory. Journal of Verbal Learning and Verbal Behavior, 13, 585-89.

MODELS OF MEMORY

310

- CRAIK, F.I.M. \& LockharT, R.S. (1972).

Levels of processing: A framework for memory research. Journal of Verbal Learning and Verbal Behavior, 11, 671-84.

\section{Perception}

Walking OfF a Cliff

- Gibson, E.J. \& WALK, R.D. (1960). The 'visual cliff'. Scientific American, 202, 64-71.

Why Did the Antelope Cross the Road?

- DeREgowsKi, J.B. (1972). Pictorial perception and culture. Scientific American, 227, 82-88.

Will the Real Ralph Richardson Please Stand Up

- Young, A.W., Hay, D.C. \& Ellis, A.W. (1985).

The faces that launched a thousand slips:

Everyday difficulties and errors in recognizing people.

British Journal of Psychology, 76, 495-523.

\section{Mind}

Autism And Theories of Mind

- Baron-Cohen, S., Leslie, A.M. \& Frith, U. (1985).

Does the autistic child have a 'theory of mind'?

Cognition, 21, 37-46.

I'M SORry Dave, I CAN't Do That

- Searle, J.R. (1980). Minds, brains, and programs.

The Behavioral and Brain Sciences, 3, 417-57. 


\section{Part VI: Health Psychology}

19 Stress and Coping

LIFE IS STRESS

- Holmes, T.H. \& RAHE, R.H. (1967). The social re-adjustment rating scale. Journal of Psychosomatic Research, 11, 213-18.

STRESS? I CAN HANDLE IT!

- Billings, A.G. \& Moos, R.H. (1981). The role of coping responses and social resources in attenuating the stress of life events. Journal of Behavioral Medicine, 4, 139-57.

AIDS AND UNCERTAINTY

Weitz, R. (1989). Uncertainty and the lives of persons with AIDS, Journal of Health and Social Behavior, 30, 270-81.

\section{Health Behaviour}

Type A OR Not Type A

- Friedman, M. \& Rosenman, R.H. (1959). Association of specific overt behavior pattern with blood and cardiovascular findings. Journal of American Medical Association, 169, 1286-96.

IN CONTROL

LANGER, E.J. \& RoDIN, J. (1976). The effects of choice and enhanced personal responsibility for the aged: A field experiment in an institutional setting. Journal of Personality and Social Psychology, 34, 191-98.

Where Does It Hurt?

- Melzack, R. (1992). Phantom limbs. Scientific American, April, 90-96

\section{PART VII: Methodology}

21 Frameworks and Approaches

- ORNE, M.T. (1962). On the social psychology of the psychological experiment: With particular reference to demand characteristics and their implications. American Psychologist, 17, 776-83. 
Dull Rats AND BRight Rats

402

- Rosenthal, R. \& Fode, K.L. (1963). The effect of experimenter bias on the performance of the albino rat. Behavioral Science, 8, 183-89.

TeAChers' Bloomers

- Rosenthal, R. \& Jacobson, L. (1966). Teachers' expectancies: Determinants of pupils' I.Q. gains. Psychological Reports, 19, 115-18.

Who Are Psychology's Subjects?

- SEARS, D.O. (1986). College sophomores in the laboratory: Influences of a narrow data base on psychology's view of human nature. Journal of Personality and Social Psychology, 51, 513-30

Discourse AnAlysis

- PotTer, J. \& EdWARds, D. (1990). Nigel Lawson's tent: Discourse analysis, attribution theory and the social psychology of fact. European Journal of Social Psychology, 20, 405-24.

A RePERTORY GRID STUdy OF MANAGERS

- Brown, C.A. \& Detoy, C.J. (1988). A comparison of the personal constructs of management in new and experienced managers.

In F. Fransella \& L. Thomas (eds), Experimenting with Personal Construct Psychology. London: Routledge and Kegan Paul.

Suggested Answers

Glossary

References

Index 


\section{LIST OF Figures}

1.1 The percentage of correct answers for each critical trial 6

1.2 Percentage of errors made compared with the number of confederates

1.3 Layout of adjacent and critical areas of subway car 12

1.4 What the 'learner' said while he was being 'shocked' 19

1.5 The number of people who continued to obey the experimenter as the voltage increased

2.1 Number of situational and dispositional explanations given by subjects for their own and their best friend's choice of girlfriend

2.2 Cognitive dissonance: balancing a lie with a bribe 39

2.3 How enjoyable were the tasks? 41

3.1 The 'prisoners' in the prison simulation study 47

3.2 Average proportion of acts in the main areas of Bales' taxonomy

4.1 Sociograms of group structure $\quad 62$

6.1 Visual pathways in the brain 98

6.2 Self reports of emotion in the various conditions of the Schachter and Singer experiment 107

6.3 The recall of dreams after REM and non-REM sleep 112

7.1 A summary history of all the social groups 120

7.2 The stages of mating in the stickleback 124

7.3 Effect of population density on behaviour 130

8.1 The selection of girls or women for high and low-status jobs

8.2 Feedback on correctness of work $\quad 145$

8.3 Percentage of the total positive feedback and total negative feedback

8.4 Percentage of positive work-related feedback and negative work-related feedback 
8.5 Drawing of a premenarcheal girl, time 1 151

8.6 Drawing of a premenarcheal girl, time 2 151

8.7 Drawing of a postmenarcheal girl, time 1 152

8.8 Drawing of a postmenarcheal girl, time 2 152

8.9 Drawing of a girl whose menarcheal status changed over course of study - premenarcheal, time 1 153

8.10 Drawing of a girl whose menarcheal status changed over course of study - postmenarcheal, time 2

9.1 Distribution of ratings 167

9.2 Acceptance of sketch items 168

10.1 Part six of examination Beta for testing innate intelligence 173

10.2 Choices of doll 'they want to play with' and 'nice doll' 180

11.1 Responses of medical staff to a simple request from pseudopatients 194

11.2 Letter from Eve 204

11.3 Snake avoidance scores for experimental and
control groups

12.1 Number of adolescents with special same-sex friend 226

14.1 Average number of errors made by the children 265

14.2 Classical conditioning 269

15.1 Frame by frame microanalysis of sound and movement 281

16.1 Example of successive reproductions 300

16.2 Example of successive reproductions 302

16.3 Speed estimates for the different verbs used in the
witness question

16.4 Response to the question 'Did you see any broken glass?' 307

16.5 Traditional multi-store model of short-term and long-term memory 311

17.1 The effect of context on the perception of a simple shape 318

17.2 The visual cliff 320

17.3 Pictorial depth perception 325

17.4 Ambiguous trident 326

17.5 Elephant drawing: split-view and top-view perspective 327

17.6 Some faces in a crowd often look a bit familiar even when they are not 333

18.1 Experimental scenario 342

18.2 Examples of Chinese characters 347

19.1 The experience of stress 361

20.1 Change in self-reports of the residents 385

20.2 Phantom limbs 388 
XVi LIST OF FIGURES

$21.1 \quad$ Example of a T-maze 403

21.2 Average number of correct responses per rat per day 405

21.3 Subject populations and research sites in social psychology articles $1980 \quad 414$

21.4 Nigel Lawson looking for a conspiracy 422

21.5 The structure of a repertory grid 427 


\section{LIST OF TABLES}

1.1 Distribution of age and occupational types in the Milgram study

2.1 Actors' and observers' estimates of the probability that the actor would volunteer for a similar task, as a function of whether or not the actor volunteered to entertain the 'important visitors'

2.2 Number of entity (situational) reasons and dispositional reasons given by subjects as explanations of their own and their best friend's choices of girlfriend

2.3 Mean number of traits (out of possible 20) that were ascribed to each stimulus person

2.4 Replies to the question, 'Will you accept members of the Chinese race as guests in your establishment?'

2.5 Average ratings on interview questions for each condition

3.1 Average proportion of acts in each category of Bales' taxonomy

6.1 Which hemisphere deals with sources of information

6.2 The conditions in the Schachter and Singer experiment

6.3 The self-report rating scale used by Schachter and Singer

6.4 The recall of dreams after REM and non-REM sleep

106

6.5 Results of dream-duration estimates after 5 or 15 minutes of rapid eye movements

8.1 Contingency table showing subjects' selections of candidates for high and low-status jobs

9.1 Distribution of ratings

9.2 Distribution of 'true' responses

9.3 Group acceptance of sketch items 168

10.1 Percentage responses to the doll questions 180

10.2 Similarities between political and scientific colonialism 185

10.3 Differences between African and European world views 186 
11.1 Judgement of all admission patients as to the likelihood that they are pseudopatients

11.2 Self-initiated contact by pseudopatients with psychiatrists, nurses and attendants

11.3 Rank ordering of ten types of therapy

11.4 The snake avoidance test: experimental design

11.5 Number of subjects who held or touched the snake during the avoidance test

11.6 Mean snake avoidance scale scores at Tests 2 and 3, mean change scores, and the Mann-Whitney U-test

12.1 Teachers' assessment of popularity with peers

13.1 Contingency table showing moral orientation by gender

13.2 Bandura's eight experimental groups

13.3 Mean aggression scores for experimental and control subjects

14.1 Mean errors of judgement for all the tests 265

14.2 Mean errors of judgement for all ages

15.1 Correspondence of infant movements with live speech

15.2 Correspondence of infant movements with recorded speech and non-speech sounds

16.1 Speed estimates for the verbs used in the estimation of speed question

16.2 Response to the question 'Did you see any broken glass?' 307

18.1 The percentage of correct responses to each of the four 'Sally-Anne' questions

19.1 Characteristics of the sample 355

19.2 Social re-adjustment rating scale 357

19.3 Composition of method and focus of coping measures 362

19.4 Mean percentage of coping responses for each type of stressful event

19.5 AIDS

20.1 Type A and Type B behaviour patterns 374

20.2 A comparison of the subjects who displayed Pattern A and Pattern B behaviours

20.3 A comparison of blood and illness for Group A and Group B

20.4 Locus of control

20.5 Average scores for self-report, interviewer ratings and nurse ratings

$21.1 \quad$ Number of correct responses per rat per day 
21.2 Mean time in minutes required to make correct response 406

21.3 Percentages of experimental and control Ss gaining 10, 20 or 30 IQ points

21.4 Subject populations and research sites in social psychology articles in 1980 and 1985

21.5 Examples of the construct labels from new and experienced managers 


\section{Preface}

Psychology is based on evidence from research studies. The main conclusions from these studies are often gathered together and put into a text book of psychology, but the details of the studies are usually left out. In this book we are presenting the details of sixty-four research studies that we think reflect the discipline of psychology. Our aim is to provide clear and accurate summaries of these important pieces of work in psychology so that you can weigh up the evidence for yourself and come to your own conclusions about what it means.

Students often do not have the opportunity to read original research articles. There are a number of reasons for this including the major problem that many of the important articles are not readily available. Even if you have access to a good library, then it takes a long time to search out the material you are looking for, and when you find the original research study it is often written in an impenetrable style.

We have tried to address these problems in this book. We are presenting the studies in a clear style (we hope), with enough details for you to be able to get a good idea of the research, and all in one volume so you do not have to trail round the local university library. The summaries are written with a brief introduction to provide some background for the research. Then we describe how the work was carried out and what was found, and we add some comments at the end to suggest one or two possible criticisms or further developments. Questions are included after each summary (with suggested answers at the back of the book) to help consolidate and develop what you have learnt.

Having read the summaries you should find the original papers relatively easy to follow, and we would encourage you to track down any that you find particularly interesting. Our feeling is that reading journal articles is a skill that needs to be developed, rather than something we can all just (magically) do. Indeed, one intention of this book is to provide an intermediate stage between standard textbooks and 
the original articles upon which those textbooks (and the entire discipline of psychology) are based.

In the limited space of one book we can only present a small number of studies. We have been incredibly selective, especially when you consider that thousands of pieces of research are published every year. We have chosen our studies to illustrate how psychology has developed over the years, and we have tried to present a range of studies that illustrate the breadth of psychological research covering the areas of biological psychology, comparative psychology, social psychology, human diversity, developmental psychology, cognitive psychology and health psychology. We have also taken care to include studies that reflect the wide range of methods used by psychologists in their research, from hard-nosed experimentation to in-depth interviewing and literature searches.

Psychological evidence is still mainly presented in the form of research papers, and the studies we have chosen reflect the way that psychology is being conducted and reported. The summaries are presented in parts that are based on the traditional research areas of the subject. It is worth noting, however, that the divisions between the different areas are sometimes quite arbitrary and most of the studies have relevance in more than one area.

We hope that this book encourages you to read further in the subject and to dig out some of the original papers if you can. We also hope that you enjoy reading the material and find it as provocative and interesting as we do. Most importantly, though, we hope that you develop your own opinions about psychology drawing on the evidence presented in this text.

We would like to acknowledge the support of our colleagues in the Psychology Division at The Nottingham Trent University who provide a positive and friendly working environment.

Phil Banyard Andy Grayson 


\section{ACKNOWLEDGEMENTS}

The authors and publishers wish to thank the following for permission to use copyright material.

Academic Press, Inc. for material from E.F. Loftus \& J.C. Palmer, 'Reconstruction of auto-mobile destruction', Journal of Verbal Learning and Verbal Behavior, 13, 1974, Tables 1, 2 (pp. 306, 307). American Association for the Advancement of Science for material from W.S. Condon \& L.W. Sander, 'Neonate movement is synchronized with adult speech: Interactional participation and language acquisition', Science, 183, 1974, Tables 1, 2, adapted, pp.99-100, Figure 1, p. 100 (pp. 279-81). Copyright (C) 1974 American Association for the Advancement of Science; and D. L. Rosenhan, 'On being sane in insane places', Science, 179, 1973, Table 1. Copyright (C) 1973 American Association for the Advancement of Science (pp.192, 194). American Medical Association for material from M. Friedman \& R.H. Rosenman, Association of specific overt behaviour pattern with blood cardiovascular findings', Journal of American Medical Association, 169, 1959, Tables 1, 2. Copyright (C) 1959 American Medical Association (p. 377). American Psychological Association for material from P.J. Lang \& A.D. Lazovik, 'Experimental desensitisation of a phobia', Journal of Abnormal and Social Psychology, 66, 1963, Tables 1, 2, 3, pp. 522, 523 (pp. 211-12); E.J. Langer \& J. Rodin, "The effects of choice and enhanced personal responsibility for the aged: A field experiment in an institutional setting', Journal of Personality and Social Psychology, 34, 1976, Table 1, p. 195 (p. 384); J. Hraba \& G. Grant,'Black is beautiful: A re-examination of racial preference and identification', Journal of Personality and Social Psychology, 16, 1970, Table 1, adapted, p. 399 (p. 180); an illustration from I. Piliavin, J. Rodin \& J. Piliavin, 'Good samaritanism: An underground phenomenon?' Journal of Personality and Social Psychology, 13, 1969 (p. 12); Tables 2.1, 2.2, 2.3 from R.E. Nisbett, C. Caputo, P. Legant \& J. Marecek, 'Behaviour as seen by the actor and as seen by 
the observer', Journal of Personality and Social Psychology, 27, 1973, Table 1, p. 157, adapted, Table 2, p.159, adapted, and Table 5, p.161. Copyright (C) 1963, 1976, 1970, 1969, 1973 by the American Psychological Association (pp. 27, 29, 30); and adapted tables from C.S. Dweck, W. Davidson, S. Nelson \& B. Enna, 'Sex differences in learned helplessness', Developmental Psychology, 14, 1978, pp. 268-76 (pp.145-47); Association for Child Psychology \& Psychiatry for material from J. Hodges \& B. Tizard, 'Social and family relationships of ex-institutional adolescents', Journal of Child Psychology and Psychiatry, 30, 1989, Elsevier, Table 11, p.88, Figure 2, p. 89 (pp. 225-26); and J. Samuel \& P. Bryant, 'Asking only one question in the conservation experiment', Journal of Child Psychology and Psychiatry, 25, 1984, Elsevier, Table 2, p. 317 (pp. 265-66). Behavioral Science for material from R. Rosenthal \& K.L. Fode, "The effect of experimenter bias on the performance of the albino rat', Behavioral Science, 8, 1963, Tables 1, 2, pp. 185, 186 (pp.405-6). Cambridge University Press for illustrations from F.C. Bartlett, Remembering: A Study in Experimental and Social Psychology, 1932, pp.178-80 (p. 302). Chapman \& Hall for an illustration from P. Banyard \& N. Hayes, Psychology: Theory and Application, 1994, p. 446 (p. 19). Elsevier Science Ltd for material from T.H. Holmes \& R.H. Rahe, 'The social re-adjustment rating scale', Journal of Psychosomatic Research, 11, 1967, Table 3, p. 216 (p. 357); and S. Baron-Cohen, A.M. Leslie \& U. Frith, 'Does the autistic child have a "theory of mind"?' Cognition, 21, 1985, Figure 1, p. 41 (p. 342). Sharon Golub for material from E. Koff, "Through the looking glass of menarche: What the adolescent girl sees' from Menarche, ed. S. Golub, 1983, Figures 5.1a-c, 5.2a-c, pp. 80-4 (p.151-53). Alexandra Milgram for material from S. Milgram, 'Behavioural study of obedience', Journal of Abnormal and Social Psychology, 67, 1963, Table 1 (p. 18). New Scientist for graphic from R. Rawlins, 'Forty years of rhesus research', New Scientist, 82, 1979, pp. 110 (p.120). WW. Norton \& Company, Inc. for material from Stephen Jay Gould, The Mismeasure of Man, Figure 5.5, p. 211. Copyright (C) 1981 by Stephen Jay Gould (p. 173). Plenum Publishing Corporation for material from A.G. Billings \& R.H. Moos, 'The role of coping responses and social resources in attenuating the stress of life events', Journal of Behavioral Medicine, 4, 1981, Tables 1, 3, pp. 146, 149 (pp. 362, 364). Psychological Reports and R. Rosenthal for material from R. Rosethal \& L. Jacobson, 'Teachers' expectancies: Determinants of pupils' IQ gains', Psychological Reports, 19, 1966, Table 2, p. 117 (p. 410). Scientific American, Inc. for illustrations by Eric Mose, from N. Tinbergen, 'The curious behaviour of the stickleback', Scientific American, 187, 
Dec. 1952, pp. 24, 25 (pp.124, 125); by Carol Woike Donner from J.B. Deregowski, 'Pictorial perception and culture', Scientific American, 227, Nov. 1972, pp. 83, 86 (pp. 325, 326, 327); by Sarah Love from Robert F. Bales, 'How people interact in conferences', Scientific American, 192, March 1955, p. 35 (p. 54) and Muzafer Sherif, 'Experiments in group conflict', Scientific American, 195, Nov. 1956, p. 57 (p.62); and by Bunji Tagawa from John B. Calhoun, 'Population density and social pathology', Scientific American, 206, Feb. 1962, pp. 140-1 (p.130). Camera Press London for the photograph on p. 333; Popperfoto for the photograph on p.422; and Philip Zimbardo for the photograph on p. 47.

Every effort has been made to trace all the copyright holders, but if any have been inadvertently overlooked the publishers will be pleased to make the necessary arrangement at the first opportunity. 